УДК $372.881 .1+808.5$

DOI https://doi.org/10.32782/apv/2021.3.11

\title{
Наталія ІОВХІМЧУК
}

кандидат філологічних наук, дочент, кафедри теорії та методики початкової освіти, Волинський національний університет імені Лесі Українки, просп. Волі, 13, м. Луцьк, Волинська область, Україна, 43025

ORCID: 0000-0002-4617-3535

Бібліографічний опис статті: Іовхімчук, Н. (2021). Формування культури мовлення учнів початкової класів. Acta Paedagogica Volynienses, 3, 69-75, doi: https://doi.org/10.32782/apv/2021.3.11

\section{ФОРМУВАННЯ КУЛЬТУРИ МОВЛЕННЯ УЧНІВ ПОЧАТКОВИХ КЛАСІВ}

\begin{abstract}
У статті розглядається проблема формування культури мовлення молодших школярів на уроках украӥнської мови. Актуальність і недостатня розробленість проблеми, ї̈ значення для вдосконалення навчально-виховного процесу нової української школи та задоволення вимог сучасного суспільства зумовили вивчення теоретичних і практичних аспектів проблеми формування культури спілкування, стану цієї проблеми в шкільній практиці. Проаналізовано останні дослідження й публікаиії щзодо навчання мови, визначено мету дослідження, окреслено низку питань, присвячених висвітленню в сучасній лінгводидактичній літературі стану дослідження проблеми вдосконалення культури мовлення молодших школярів, щчо дає підстави створювати відповідну систему розвитку мовлення, удосконалювати способи й засоби навчання. У дослідженні використовувалися такі методи дослідження: теоретичні: аналіз і синтез психолого-педагогічної, лінгвістичної і методичної і літератури; емпіричні: спостереження та аналіз уроків украӥнської мови з метою визначення недоліків і мовленнєвих труднощів, з якими стикаються учні під час спілкування.

Культурі спілкування завжди притаманні етнічні особливості, начіональна своєрідність. Щодо мовленнєвого етикету українців, то в ньому відбито такі риси, як пошана до батьків, до жінки, демократичність поглядів, емоційність висловлювань, естетизм почуттів, побожність та ін. У мовленні формуються не лише пізнавальні можливості людини, а й інтегральні складники психічного життя: самооцінка, усвідомлення власної значущьості та відчуття ї̈ тотожності в будь-яких життєвих ситуаціях. Уже в ранньому віці в дитині закладаються основи ї̈ культури, у тому числі і культури спілкування. Маючи певний досвід, людина протягом життя прагне до ї̈ підвищення. Аналіз наукової літератури, запропонована система вправ та завдань спрямована на формування вмінь культури мовлення молодших школярів.
\end{abstract}

Ключові слова: культура, мовлення, мова, культура мовлення, молодші школярі, підвищення культури мовлення.

\section{Nataliia IOVKHIMCHUK}

Candidate of Philological Sciences, Senior Lecturer at the Department of Theory and Methods of Primary Education, Lesya Ukrainka Volyn National University, 13 Voli Ave, Lutsk, Volyn region, Ukraine, 43025

ORCID: 0000-0002-4617-3535

To cite this article: Iovkhimchuk, N. (2021). Formuvannia kultury movlennia uchniv pochatkovoi klasiv [Formation of speech culture of primary school students]. Acta Paedagogica Volynienses, 3, 69-75, doi: https://doi.org/10.32782/apv/2021.3.11

\section{FORMATION OF SPEECH CULTURE OF STUDENTS OF ELEMENTARY CLASSES}

The article deals with the problem of the formation of the culture of speech of primary school children at the lessons of the Ukrainian language. The relevance and insufficient elaboration of the problem, its importance for improving the educational process of the new Ukrainian school and meeting the requirements of modern society led to the study of theoretical and practical aspects of the problem of forming a culture of communication, the state of this problem in school practice. The latest research and publications on language teaching were analysed, the objectives of the study were determined, a number of issues were identified on the coverage in modern linguodidactic literature of the state of research on the problem of improving the speech culture of primary school children, which gives grounds to create an appropriate system for the development of speech, improve the methods and means of teaching. The research used the following research methods: theoretical: analysis and synthesis of psychological, pedagogical, linguistic and methodological literature; empirical: observation and analysis of Ukrainian language lessons in order to determine the shortcomings and speech difficulties that students face during communication. 
The culture of communication is always inherent in ethnic characteristics, national originality. According to Ukrainian speech etiquette, it reflects such features as respect for parents, for a woman, democratic views, emotionality of statements, aestheticism of feelings, piety, etc. In a speech, not only the cognitive capabilities of a person are formed, but also integral components of mental life: self-esteem, awareness of one's own significance and a sense of its identity in any life situations. Already at an early age, a child lays the foundations of his culture, including the culture of communication. Having a certain experience, a person strives to improve it throughout his life. Analysis of scientific literature, the proposed system of exercises and tasks, is aimed at developing the skills of the speech culture of primary schoolchildren.

Key words: culture, speech, language, a culture of speech, junior schoolchildren, raising the culture of speech.

Актуальність проблеми. Сучасний етап розвитку нової української школи характеризується посиленням уваги до мовної освіти, потребою формування особистості, яка відзначалася б високою культурою спілкування в різних життєвих ситуаціях.

Знання властивостей культури мовлення та спілкування $є$ актуальним на всіх етапах опанування школярами мовленнєвої грамотності. Особливого значення проблема культури мовлення набуває в початковій школі.

Протягом життя кожен із нас постійно спілкується з різними людьми. У спілкуванні реалізується потреба однієї людини в іншій. Під час спілкування люди обмінюються інформацією, впливають один на одного, розвиваються духовно, формуються як суспільні об'єкти. Потреба спілкування $\epsilon$ первинною потребою людини. Спілкуючись, людина не тільки сприймає чи передає інформацію, а й звертається з проханням, подякою, запитанням чи вимогою, ставить собі за мету вплинути на співрозмовника, одержати потрібну відповідь тощо.

У процесі свого розвитку суспільство поступово виробляє певні зразки поведінки, які визначають правила взаємодії та взаємостосунків між людьми і функціонують як суспільні норми. Ці норми у різних спільнотах можуть істотно відрізнятися. Мовленнєвий етикет потрібно розглядати як явище загальнолюдське, оскільки він відтворює національний характер будь-якого народу, тобто його ментальність.

Культурі спілкування завжди притаманні етнічні особливості, національна своєрідність. Щодо мовленнєвого етикету українців, то в ньому відбито такі риси, як пошана до батьків, до жінки, демократичність поглядів, емоційність висловлювань, естетизм почуттів, побожність та ін. У спілкуванні формуються не лише пізнавальні можливості людини, а й інтегральні складники психічного життя: самооцінка, усвідомлення власної значущості та відчуття її тотожності в будь-яких життєвих ситуаціях.
Проте в сучасному суспільстві наша культура, наша ввічливість, ставлення до безпосереднього співрозмовника та до інших учасників спілкування ще досить низька, низьким $є$ і рівень володіння мовленнєвим етикетом, який має велике значення для життєдіяльності суспільства і функціонування мови. Саме у спілкуванні найяскравіше виявляються стан мовленнєвої культури, духовні цінності, етнічні риси суспільства, рівень стосунків між людьми. Адже рівень дотримання норм мовленнєвої культури часом впливає на поведінку співрозмовника більшою мірою, ніж предметний зміст мовлення.

Уже в ранньому віці в дитині закладаються основи іiі культури, у тому числі і культури спілкування. Маючи певний досвід, людина протягом життя прагне до іiі підвищення. До цього ii підштовхує бажання постійно відкривати для себе щось нове в довкіллі. Якщо культура спілкування закладена в людині 3 дитинства і стає нормою їі життя, то вона буде проявлятися і в щоденних, і в екстремальних ситуаціях, тобто несвідомо.

Однак попри успіхи проблема формування культури спілкування учнів початкових класів ще не знайшла реалізації, тому що у дослідженнях розглядаються лише окремі аспекти проблеми. Актуальність і недостатня розробленість проблеми, iii значення для вдосконалення навчального процесу та задоволення вимог сучасного суспільства зумовили вивчення теоретичних і практичних аспектів проблеми формування культури спілкування, стану цієї проблеми в шкільній практиці.

Аналіз останніх досліджень та публікацій. Культуру мовлення як актуальне завдання розвитку лінгвістичної науки досліджували відомі науковці (Н.Д. Бабич, І.К. Білодід, І.Б. Голуб та ін.) і методисти (Л.І. Мацько, O.M. Семеног, М.I. Пентилюк та ін.), у працях яких висвітлюються теоретичні засади розуміння поняття «мовленнєва культура», іiі основні риси та характеристики, прийоми і засоби формування. 
Проблемі розвитку мовлення у навчальновиховному процесі надавали великого значення М. Вашуленко, О. Горошкіна, В. Мельничайко, М. Пентилюк, Г. Сагач, І. Синиця, Л. Скуратівський, О. Хорошковська, Г. Шелехова. У їхніх працях наголошується на необхідності формування в школярів культури спілкування як складової частини успішного мовлення, містяться певні методичні рекомендації. Терміном «культура спілкування» послуговувалися у своїх працях такі автори, як: В. Гозман, Л. Петровська, Я. РадевичВинницький, Л. Соловець, Т. Чмут та ін.

Аналіз педагогічної, методичної літератури, присвяченої проблемі мовленнєвого розвитку учнів, засвідчує, що науковці торкалися питань культури мовлення і розвитку мовленнєвих здібностей учнів. Для представників мовознавчої науки центральною стає постійна увага до питань народного світогляду, народної психології, поведінки людини як носія національного характеру (В. Жайворонок, Л. Мацько, В. Кононенко).

Метою дослідження $є$ формування культури спілкування молодших школярів на уроках української мови.

Виклад основного матеріалу дослідження. Найважливішою сферою людських стосунків є спілкування, у якому виявляється найперша соціальна потреба людини - потреба в іншій людині.

Важливим є 3'ясування суті поняття «культура мовлення». Відомо, що мова - це система засобів спілкування, яка існує у свідомості носіїв. «Мова - явище соціальне. У повному обсязі вона може існувати тільки у спільноті людей» (Глазова, Кузнецов, 2006, с.140).

Мова також незалежна від обставин спілкування. Свою комунікативну та інші функції мова реалізовує лише через мовлення, під яким розуміють сам процес говоріння і його результати. «Мовлення, - як зауважує О. Сербенська, - активне, динамічне, є виявом вільної творчої діяльності індивіда, відбиває його компетенцію. Мовлення конкретне, має певну мету, зумовлене ситуативно, у ньому можливі елементи випадкового. Це - конкретне говоріння, яке відбувається у часі і має звукову чи письмову форму» (Сербенська, 2001, с. 20).

У кожної людини мовлення індивідуальне, проте, на думку М. Кочергана, воно не настільки відрізняється, щоб заважати взаєморозумінню. Усі людські зразки мовлення, узяті в сукупності, це і $є$ їхня мова в різних реалізаціях (Кочерган, 2006, с. 12). Однак основна мета співрозмовників полягає не в тому, щоб відтворювати мову й демонструвати свої мовленнєві здібності, а щоб передати інформацію, обмінятися нею чи вплинути на інших учасників комунікативного акту. Отже, мова - це система засобів спілкування, за якою створюється мовне повідомлення, це сукупність правил, за якими будується мовлення, а мовлення - це використання цих правил і засобів мови окремими людьми під час спілкування.

Культура людини - це культура іiі мовлення; людина, байдужа до власного мовлення, дикун. Допоки у вихованні нових поколінь ігноруватиметься роль мовного виховання, нам не домогтися високого рівня загальної культури суспільства. (Бабич, 2006, с. 76) Мовна культура загалом - поняття дуже широке й багатогранне (Омельчук, 2006, с. 8-17). Ми зосередимо увагу лише на аспектах, пов'язаних 3 гармонійними міжособистісними стосунками, і які мають відношення до культури спілкування.

Культура мови - це володіння нормами літературної мови, уміння користуватися іï виражальними засобами у різних умовах спілкування відповідно до мети і змісту мовлення. Крім цього, як зазначає А. Коваль, «вона передбачає смислову точність, багатство і різноманітність словника, логічну послідовність, чіткість, художню виразність тощо» (Koval, 1986, pp. 9-52).

За словником-довідником 3 української лінгводидактики, культура мовлення - це дотримання літературних норм вимови, слововживання, побудови словосполучень, речень, текстів; нормативність усного і писемного мовлення, що виражається в іiі правильності, точності, ясності, чистоті, логічності, доречності, виразності, а також у різноманітності граматичних конструкцій, багатстві словника, дотриманні в писемному мовленні орфографічних і пунктуаційних норм (Захлюпана, 2002, с. 77).

Б. Головін визначає культуру мовлення як:

1) володіння літературними нормами на всіх мовних рівнях, в усній і письмовій формах мовлення, уміння користуватися 
мовностилістичними засобами і прийомами 3 урахуванням умов і завдань комунікації;

2) упорядковану сукупність нормативних мовних засобів, вироблених практикою людського спілкування, які оптимально виражають зміст мовлення і задовольняють умови і мету спілкування;

3) самостійну лінгвістичну дисципліну (Головин, 1980, с. 7).

У «Короткому тлумачному словнику лінгвістичних термінів» подано таке визначення: «Культура мови (мовлення ) - це: 1) свідоме й критичне використання мовних засобів, володіння нормами усної та писемної літературної мови в різних сферах суспільної комунікації відповідно до мети й змісту висловлювання; 2) розділ мовознавства, а також навчальна практична дисципліна, що вивчає нормування й кодифікацію норм літературної мови, встановлює критерії нормативності й стабілізаційні процеси в літературній мові, пропагує зразки досконалої мови, а також поширює лінгвістичні знання серед носіїв мови» (Срмоленко, 2001, c. 81).

Отож поняття «культура мови» і «культура мовлення» у визначеннях мовознавців певною мірою ототожнюються. Отже, зазначимо, що культура мови - це володіння нормами літературної мови, а культура мовлення - це використання цих норм в усній і письмовій формах мовлення для досягнення мети спілкування.

Сьогодні одним із принципів перебудови навчання у школі $є$ принцип діалогізації педагогічної взаємодії. Діалогічне спілкування дає змогу досягнути глибшого взаєморозуміння і саморозкриття співрозмовників. Діалогічна взаємодія - це особистісно рівноправні позиції, де домінують мотиви самоактуалізації й саморозвитку співрозмовників.

Високий рівень культури мовлення передбачає знання особистісних якостей адресата й адресанта і врахування їх у конкретних ситуаціях відповідно до моральних правил і норм. Звичайно, уміння переконувати залежить не лише від особистості адресата, а й від уміння будувати власне висловлювання.

Вважаємо, що культура мовлення є складовою частиною культури людини в цілому і має три компоненти: психологічний (здатність розпізнавати психологічні настрої співрозмовника, адекватно реагувати на його поведінку), моральний (поєднання моральної свідомості і відповідної культури поведінки у необхідних життєвих ситуаціях) i мовленнєвий (дотримання культури мовлення, мовленнсвого етикету у щоденних ситуаціях спілкування).

Для культури мовлення характерні певні норми, які окреслюють правила спілкування людей у тій чи іншій ситуації і визначаються станом суспільства, його традиціями, національною своєрідністю, загальнолюдськими цінностями.

Культура мовлення українців тісно пов'язана 3 їхньою ментальністю. Тому в мовленнєвому етикеті простежуються такі риси, як пошана до батьків, жінки, делікатність у висловленнях i поведінці, емоційність, демократизм, естетизм, співчутливість, щирість, доброзичливість, набожність тощо. Це спостерігається в розвитку не лише людини зокрема, а й української сім'ї в цілому. Так, про доброзичливість українців свідчить ціла низка формул вітання і побажання (доброго ранку, добридень, на добраніч, доброго здоров'я), про гостинність свідчать інші етикетні вислови (гостинно просимо, частуйтеся, пригощайтеся, будьте як у себе вдома), емоційність та естетизм виражаються у зменшувальнопестливих суфіксах етикетних слів звертання (як здоров'ячко, кумонько моя, голубонько люба, подружечко єдина), індивідуалізм простежується в повазі до кожного члена родини, наприклад, під час звертання: і до малого, і до старого (господине дорога, пане господарю, дівчинонько гожа, парубче гречний) тощо.

Про значення моральності спілкування для українців (зокрема, про бажання добра) наголошував і відомий педагог В. Сухомлинський: «Уміння відчувати, по-хорошому бачити людей - не тільки показник етичної культури, а й результат внутрішньої духовної роботи. Добрі побажання живуть у душі того, хто вміє віддавати сили своєї душі іншим людям» (Сухомлинський, 1987, с. 191).

Сучасний світ із мобільним телефоном (виробленими правилами культури спілкування як усним видом спілкування), мережею Інтернет (культура спілкування в мережі як письмова форма спілкування) багато чого змінилось і в культурі спілкування українців. Однак основа культури спілкування українців незмінна - це збереження доброзичливих стосунків між людьми, утвердження толерантності. 
Рівень культури мовлення залежить і від якостей самої особистості. Щоб спілкування було справді глибоким і успішним, необхідно, крім знань про спілкування, певних умінь i навичок, мати у першу чергу «комунікативногуманістичну настанову на спілкування, налаштування на людину як на найвищу цінність» (Войскунский, 1990, с. 148).

Формувати вміння культури мовлення потрібно на уроках, безпосередньо присвячених опрацюванню цього виду роботи, а також на уроках розвитку мовлення та вивчення мовного матеріалу, інтегруючи теми дослідного навчання у пропоновані чинною програмою теми.

Створюючи вправи і завдання з формування культури мовлення, варто враховувати підпорядкованість завдань темі, тобто певній ситуації спілкування. Подаємо зразки таких завдань:

Завдання 1. Розіграйте діалог, використовуючи формули мовленнєвого етикету відповідно до ситуації спілкування.

Уяви, що до вашого класу прийшов новий учень. Його посадили 3 тобою за одну парту. Познайомся 3 новеньким, запитай, звідки він перейшов у вашу школу. Розкажи про свою школу, покажи, де розташовані спортзал, бібліотека, їдальня, кабінет директора, медпункт. Покажи йому розклад уроків, познайом із друзями.

Завдання 2. Розкажіть про людину, яка, на вашу думку, уміє (або не вміє) спілкуватися. Аргументуйте свою думку.

Завдання 3. Поспілкуйтеся в мережі Інтернет 3 друзями. Виявіть і запишіть, які мовленнєві помилки ви помітили під час спілкування. Чи вживаєте у такому спілкуванні формули мовленнєвого етикету? Чому?

Завдання 4. Уявіть: ви щойно приїхали до санаторію. Перший день. Вам потрібно познайомитися 3 однолітками. Назвіть своє ім'я і зверніться до них на ім'я у кличному відмінку. Складіть діалог.

Завдання 5. Уявіть собі, що вас запросили в гості. Пригадайте правила поведінки у гостях. Підкресліть дієслова у тексті. Назвіть формули подяки за смачну їжу.

Коли їси, сиди прямо, не клади лікті на стіл. Не можна їсти з ножа. Якщо користуєшся ножем, виделку тримай у лівій руиі. Голосно не розмовляй. Не розмахуй руками. Коли пойси подякуй.
Завдання 6. Назвіть основні правила культури мовлення по мобільному телефону.

Завдання 7. Прочитайте правила спілкування по мобільному телефону. Скажіть, чи дотримуєтеся всіх зазначених правил? Про які правила дізналися вперше? Якими рекомендаціями хотіли б доповнити правила спілкування по телефону?

Для читання вголос і мовчки для учнів початкових класів варто використовувати тексти 3 дитячої української художньої та публіцистичної літератури, українського фольклору, у яких йдеться про спілкування, культуру мовлення.

Культура писемного мовлення полягає у формуванні вмінь створювати і оформляти тексти у письмовому вигляді (лист, запрошення, прохання, спілкування в мережі Інтернет, sms-повідомлення тощо) відповідно до норм культури спілкування. Наводимо зразки таких завдань.

1. Напишіть листи: а) матері; б) молодшому братові чи сестрі; в) класному керівникові; г) шкільній подрузі чи другові. Поясніть, які формули етикету спілкування ви використаєте i чому саме такі. Яке значення для ефективного спілкування має почерк адресата, грамотне оформлення висловлювань?

2. Підготуйте висловлювання на тему: «За що я люблю книги?» або «Яке значення для людини має читання книг, журналів, газет?», використовуючи формули мовленнєвого етикету відповідно до ситуації спілкування і дотримуючись вимог до створення монологу.

3. Уявіть, що у Вас незабаром день народження. Подумайте, кого Ви хотіли б запросити (напишіть список), придумайте текст запрошення. Чи відрізнятиметься текст запрошення залежно від віку, посади, соціального стану запрошених? Чому?

4. Подумайте, якого змісту ви пишете щодня такі повідомлення. Проаналізуйте збережені повідомлення у своєму телефоні, чи дотримуєтеся ви правил написання таких повідомлень? Напишіть sms-повідомлення про термінове проведення батьківських зборів у вашому класі.

Ураховуючи вікові особливості учнів, доречним середовищем для формування вмінь культури спілкування є створення сюжетних, рольових ігор, застосування форм інтерактивного навчання. Тут учителю особливо потрібно 
слідкувати за культурою мовлення учнів, тобто звертати увагу на правильне наголошування слів, уживання їх у потрібному відмінку, уникати явищ тавтології і багатослів'я, правильно творити числівникові форми, не порушувати лексичну сполучуваність слів, запобігати помилкам у дієвідмінюванні дієслів, пам'ятати про діалектизми та їх доречність/недоречність уживання у конкретній ситуації спілкування. Наведемо зразки таких завдань:

1. Ситуація 1. Уявіть собі, що ви всією сім'єю прийшли в гості до бабусі. На вас уже чекають дядько і тітка, їхні діти - ваші двоюрідні брати i сестри. Визначте тему й основну думку власного висловлювання, реплік мами й тата, рідні. У діалозі використайте запропоновані слова і словосполучення.

Добрий день! Як себе почуваєте? Прошу вас. Почекайте, будь ласка. Дуже вам зобов'язана. Кожен має свої справи. На все добре! Прощุaŭme!

Ситуація 2. Назустріч йде людина, яка, на вашу думку, не хоче, щоб ви іiі впізнали. Ви: а) пройдете повз неї, зробивши відсутній вигляд; б) привітаєтеся, не спинившись; в) привітаєтеся, розпочавши діалог про справи, здоров'я.

2. Тренінг «Як звертаються до старших у вашій родині?»

Перерозподіляємо групи учнів будь-яким чином - за знаками Зодіаку, кольором волосся, уподобаннями у музиці тощо. Головне, щоб дітям було комфортно і розмова знаходила відгук у їхніх серцях, викликала на щирість. Тому вчитель має уникати оцінок чи оцінювальних зауважень.

Запитання: 1. Як у вашій родині звертаються до старших - на «ти» чи на «Ви»? 2. Як ви звертаєтеся до батьків? 3.Чому саме таке звертання прийняте у вашій родині? Хто так вирішив? 4. Чи має для вас значення форма звертання до батьків? Чи головне - шанобливе ставлення до них? 5. Яке б ви хотіли почути звертання до себе від своїх дітей?

Експерт разом з учителем аналізують відповіді. (Як правило, у більшості родин звертаються до старших родичів на «ти». Діти в основному не надають формі звертання особливого значення. Майже всі опитані засвідчили, що саме на «ти» звертаються їхні батьки до своїх батьків).

Такі завдання сприяють засвоєнню теоретичного матеріалу, розвиткові навичок корис- туватися формулами мовленнєвого етикету відповідно до ситуації спілкування, засобами невербального спілкування, формуванню культури мовлення.

Робота 3 формування культури мовлення в учнів буде ефективною за умови систематичного їх впровадження на уроках. Тобто це означає поступовий перехід від ознайомлення із ситуаціями спілкування, правилами поведінки під час спілкування, основами культури спілкування до оволодіння необхідними мовленнєвими діями, а далі до вільного користування у повсякденній практиці. Учнів необхідно залучати до участі у мовленнєвій ситуації, оскільки це допомагає уникнути формальності у процесі виконання завдань, сприяє створенню природної, невимушеної обстановки.

3 огляду на те, що значну роль відіграє живе слово вчителя, тому воно повинно бути зразком мовлення для учнів у процесі вивчення мови. Надзвичайно важливо, щоб учні відчули красу, багатство і мелодійність рідної мови, щоб у них 3'явилося бажання оволодіти всіма мовними засобами, необхідність володіти знаннями про літературну мову і діалектну, розуміти їх значення і роль у культурі спілкування, важливість дотримання єдиних норм української літературної мови.

За допомогою мовних спостережень створюються умови для порівняння й аналізу лінгвістичних явищ на основі слухання розповідей учнів, учителя, магнітофонних, диктофонних, комп'ютерних, радіо-, відеозаписів (як зразки для наслідування, так і аналіз ситуацій з метою застереження).

Ефективність роботи з формування культури мовлення в учнів початкових класів залежить від іiі цілеспрямованості, систематичності і системності, урахування принципу наступності і перспективності на всіх етапах навчання.

У сучасних підходах до формування культури мовлення в учнів початкових класів розглядається як один із істотних критеріїв досягнення їхнього мовленнєвого розвитку: це вміння поєднувати правила культури поведінки, дотримання норм культури мовлення i використання формул мовленнєвого етикету у відповідних ситуаціях спілкування. Досягнення успіху в щоденних життєвих справах відбувається завдяки гармонійним гуманним стосункам і високому рівневі культури мовлення. 
Висновки та перспективи подалыших досліджень. Отже, з'ясовано, що успішність роботи 3 формування вмінь культури спілкування залежить від раціонального використання активних форм роботи учнів на уроках, методів навчання (пояснення вчителя, бесіда, виконання вправ і завдань, спостереження за мовним процесом, робота 3 літературою; інтерактивне навчання та ін. У процесі аналізу визначено теоретичні засади культури мовлення, подано завдання і вправи, реалізація яких забезпечує підвищення рівня культури спілкування молодших школярів.

\section{ЛІТЕРАТУРА:}

1. Войскунский А. Е. Я говорю, мы говорим...: Очерки о человеческом общении. М. : Знание, 1990. 238 с.

2. Глазова О. П., Кузнецов Ю. Б. Рідна мова : підруч. для 6 класу загальноосвіт. навч. закл. К. : Пед. преса, 2006. $288 \mathrm{c}$.

3. Головин Б.М. Основы культуры речи. М., 1980. 345 с.

4. Коваль А. П. Слово про слово. К. : Рад. шк., 1986. 384 с.

5. Кочерган М. П. Загальне мовознавство : підручник. К. : Академія, 2006. 464 с.

6. Культура фахового мовлення: навчальний посібник / За ред. Н.Д.Бабич. Чернівці: Книги - XXI, 2006. 496 с.

7. Культура української мови : довідник / Єрмоленко С. Я., Дзюбишина-Мельник Н. Я., Ленець К. В. та ін. ; за ред. В. М. Русанівського. К. : Либідь, 1990. 304 с.

8. Омельчук С. А. Формування мовленнєво-комунікативних умінь у процесі вивчення синтаксису. Дивослово. № 9. 2006. C. 2-4.

9. Сербенська О. А., Волощак М. Й. Актуальне інтерв’ю з мовознавцем: 140 запитань і відповідей. К. : Просвіта, 2001. 204 с.

10. Словник-довідник з методики української мови / Н. М. Захлюпана, І. М. Кочан. Л. : ЛНУ ім. І. Франка, 2002. $250 \mathrm{c}$.

11. Сухомлинський В. О. Серце віддаю дітям. К. : 1987. 543 с.

\section{REFERENCES:}

1. Voiskunskyi A. E. (1990) Ya hovoriu, mы hovorym...: Ocherky o chelovecheskom obshchenyy [I say, we say...: Essays on human communication.] M. : Znanye., 238 s. (in Russian)

2. Hlazova O. P., Kuznetsov Yu. B. (2006) Ridna mova : pidruch. dlia 6 klasu zahalnoosvit. navch. zakl. [Native language: textbook. for 6th grade general education. textbook lock] K. : Ped. presa, 288 s. (in Ukrainian)

3. Holovyn B.M. (1980) Osnovы kulturы rechy. [Fundamentals of speech culture.] M., 345 s. (in Russian)

4. Koval A. P. (1986) Slovo pro slovo [Word for word] K. : Rad. shk., 384 s. (in Ukrainian)

5. Kocherhan M. P. (2006) Zahalne movoznavstvo : pidruchnyk. [General linguistics: a textbook] K. : Akademiia, 464 s. (in Ukrainian)

6. Kultura fakhovoho movlennia: navchalnyi posibnyk [The culture of professional speech: a textbook] / Za red. N.D.Babych. (2006). Chernivtsi: Knyhy - KhKhI, 496 s. (in Ukrainian)

7. Kultura ukrainskoi movy : dovidnyk [Culture of the Ukrainian language: handbook] / Yermolenko S. Ya., Dziubyshyna-Melnyk N. Ya., Lenets K. V. ta in. ; za red. V. M. Rusanivskoho. (1990.) K. : Lybid, 304 s. (in Ukrainian).

8. Omelchuk S. A. (2006) Formuvannia movlennievo-komunikatyvnykh umin u protsesi vyvchennia syntaksysu. [Formation of speech and communication skills in the process of studying syntax] Dyvoslovo. № 9. S. 2-4. (in Ukrainian)

9. Serbenska O. A., Voloshchak M. Y. (2001) Aktualne interviu z movoznavtsem: 140 zapytan i vidpovidei. [Current interview with a linguist: 140 questions and answers] K. : Prosvita, 204 s. (in Ukrainian)

10. Slovnyk-dovidnyk z metodyky ukrainskoi movy [Dictionary-reference book on the methodology of the Ukrainian language] / N. M. Zakhliupana, I. M. Kochan. L. (2002). LNU im. I. Franka, 250 s. (in Ukrainian)

11. Sukhomlynskyi V. O. (1987) Sertse viddaiu ditiam. [I give my heart to children] K. 543 s. (in Ukrainian) 